\title{
The effect of simultaneous consumption of Ginkgo extract and Ritalin on the passive avoidance learning in male Wistar rats
}

\author{
Zohre Jafari $^{1}$, Sadaf Farhadi ${ }^{2 *}$ (D), Hamidreza Mohajerani ${ }^{3}$, Abolfazl Saeedifar ${ }^{4}$, Zhila Mohseni ${ }^{5}$ \\ 1. Assistant Professor of Biology, Department of Biology, Arak Branch, Islamic Azad University of Arak, Arak, Iran \\ 2. Graduate Student of Microbiology, Department of Biology, Arak Branch, Islamic Azad University of Arak, Arak, Iran \\ 3. Assistant Professor of Physiology, Department of Biology, Arak Branch, Islamic Azad University of Arak, Arak, Iran \\ 4. Assistant Professor of Statistics, Department of Statistics, Arak Branch, Islamic Azad University of arak, Arak, Iran \\ 5. Assistant Professor of Pharmacology, Faculty of Medicine, Arak University of Medical Sciences, Arak, Iran
}

Recieved: 7 Nov. 2018

Revised: 20 Feb. 2019

Accepted: 8 Apr. 2019

Keywords

Ritalin

Ginkgo biloba

Passive avoidance learning

\section{Corresponding author}

Sadaf Farhadi, Graduate Student of Microbiology, Department of Biology, Arak Branch, Islamic Azad University of Arak, Arak, Iran

Email: Sadaf.farhadi1337@yahoo.com

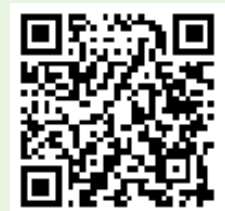

\section{Abstract}

Introduction: Ginkgo is one of the essential plants for improving memory and preventing age-related or secondary amnesia. Although it has been appeared that Ginkgo alone does not seem to increase memory, it is important to reduce amnesia. Ritalin, On the other hand, is medicine used to treat attention deficit disorder, the abuse of which harms the brain and causes dependency. This study aimed to determine the effect of Ginkgo biloba extract on Ritalin-treated rats' memory.

Methods: This experimental study was performed on 36 rats Wistar male rats, divided into 6 groups $(\mathrm{n}=6)$. The dosages used for Ritalin were $10 \mathrm{mg} / \mathrm{kg}$, and Ginkgo was $90 \mathrm{mg} /$ $\mathrm{kg}$, and $40 \mathrm{mg} / \mathrm{kg}$. Prescriptions in gavage form administrated in 10 days. The shuttle box was used to measure the amount of avoidance learning. Data were analyzed using the Kruskal-Wallis test and SPSS-23 software.

Results: The results revealed that the shuttle box test in the Ginkgo group 90mg/kg outperformed than the control group. The Ginkgo consumer group at the dose of $90 \mathrm{mg} / \mathrm{kg}$ and plus Ritalin had a significant difference with control $(\mathrm{P}<0.05)$.

Conclusion: The findings showed that Ginkgo intake of $90 \mathrm{mg} / \mathrm{kg}$ causes elevated levels of step-through latency (STL). Overall, the results of this study indicate a positive effect of Ginkgo dosages alone and with Ritalin on the avoidance learning of Ritalin-treated rats. 


\title{
تاثير مصرف همز مان عصاره جينكو و ريتالين بر يادكيرى شرطى احترازى غير فعال در موشهاى نر نزاد ويستار
}

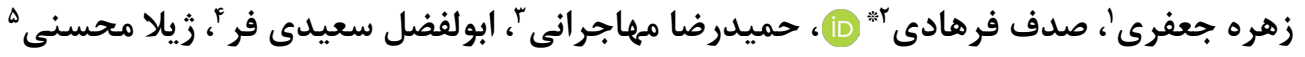

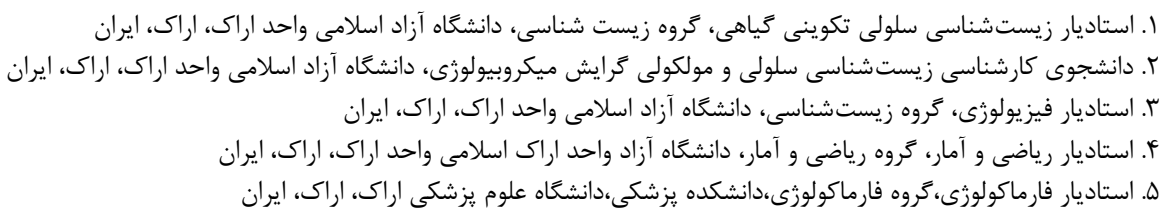

\begin{abstract}
בrs
مقدمه: يكى از كياهان مطح براى تقويت حافظه و جلـوكيرى از فراموشى وابسته به سن و يا به دليل بيمارى، كياه جينكو است. اكر حه نشان داده شده كه جينكو به تنهايى موجب افزايش حافظه نمىشود ولى در كاهش فراموشى اهميت دارد. از طرفى ريتالين يك دارو براى درمان اختلال اختلال نقص توجه و بيشفعالى است كه سوءمصرف آن اثرات زيانبارى را بر روى مغز مى حذارد و ايجاد وابستكى مى كند. هدف از اين يُوهش تعيين اثر عصاره جينكو بيلوبا بر حافظه موش هاى تحت تيمار با ريتالين بود. روش كار: اين مطالعه تجربى بر روى צ" سر موش نزاد ويستار نر كه به 9 كروه 9 تايى تقسيم شدند انجام شد. دوزهاى

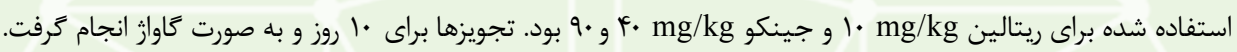
براى اندازكيرى ميزان يادكيرى احترازى از دسـتخاه شـاتل بـاكس استفاده كرديد. دادهها با استفاده از آزمون كروس كالواليس و با نرمافزار SPSS-23 ارزيابى گرديد. يافته ها: نتايج آزمون شاتل باكس در گروه مصرفكننده جينكو mg/kg •9 از بقيه گروهها بهتر بوده و كروه مصرفكننده جينكو با دوز mg/kg •9 به همراه ريتالين نيز اختلاف معنادارى با كروه كنترل داشتند (ه·/P<). نتيجه كَيرى: نتايج نشان داد مصرف جينكو mg/kg •9 باعث افزايش سطح يادكيرى شرطى احترازى غير فعال مىشود. در مجموع نتايج اين تحقيق بيان كر اثر مثبت دوز •9 جينكو به تنهايى و همراه با ريتالين بر يادكيرى احترازى موشهاى تحت تيمار با ريتالين است.
\end{abstract}

\author{
دريافت:

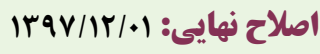

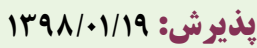 \\ وازههاى كليدى - - مازى \\ ريتالين \\ جينكو بيلوبا \\ يادكيرى شرطى احترازى غير فعال
}

نويسنده مسئول

صدف فرهادى، دانشجوى كارشناسى زيستشناسى سلولى و مولكولى گرايش ميكروبيولوزى، دانشكاه آزاد اسلامى واحد راى، اراى، ايران

ايميل: Sadaf.farhadi1337@yahoo.com

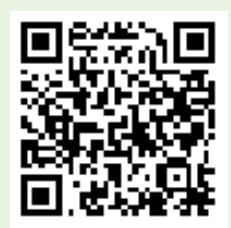

dol doi.org/10.30699/icss.21.3.65

مقدمه

اكتساب و ضبط، عموما رمزگردانى، ذخيره و بازيابى اطلاعات است، توانايى ذخيرهسازى، دست كارى و يردازش اطلاعات مرتبط با تجارب موقت و دائمى و استفاده از آنها در تعاملات بعدى با محيط مى دانند. به همين علت، حافظه در سيستم شناختى انسان، يك توانايى مركزى شناخته مىشود (ז). نورون ها در مقاطع سنى مختلف مى توانند دجار
توان يادگيرى و قدرت حافظه از ويزگى هاى بارز انسان است كه براى ادامه حيات و كذران زندگى عادى و ييشرفتهاى علمى او ضرورتى اجتنابنايذير مىباشد. حافظه را مى توان مجموعه متعدد بازتوانايى هاى شناختى دانست كه اطلاعات را نگَهدارى و تجارب گذشته فرد را براى هدف كنونى وى بازسازى مى كند ( (1). حافظه را كه شامل فرايندهاى 
نشده است، با اين وجود در ساليان اخير به برخى از اين اين عوارض

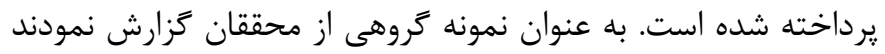

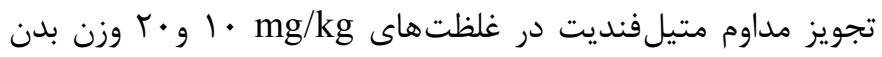
در موشهاى صحرايى موجب بروز استرس اكسيداتيو، التهاب سيستم

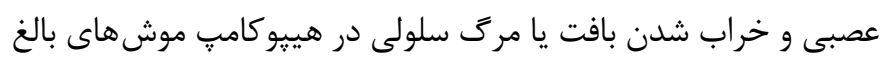

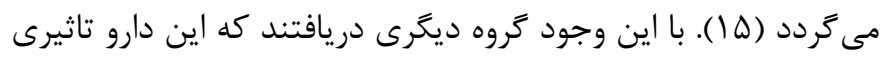

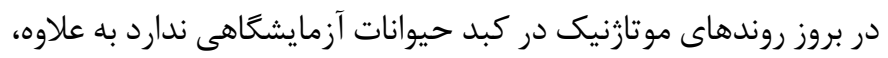
كزارش شده است كه تجويز متيلفنديت در موشهاى سورى به ميزان

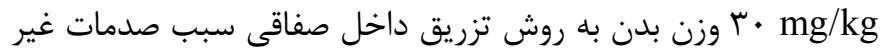
قابل بركشت در سلولهاى عصبى مىشود (91). اين محققين اثرات مضر متيلفنديت را به نقش آن در تغيير مقادير IL-1 و م

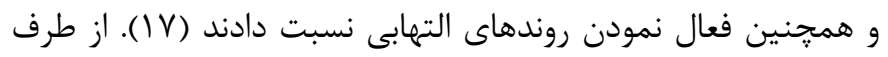

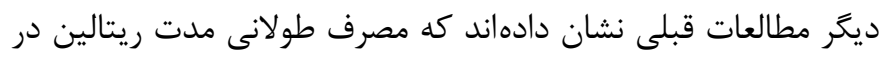

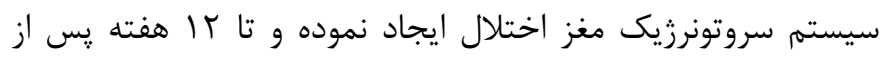

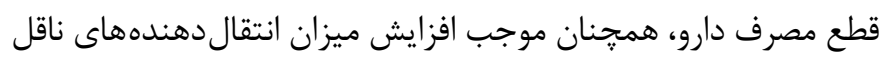

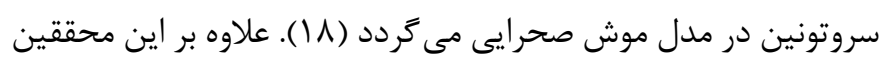

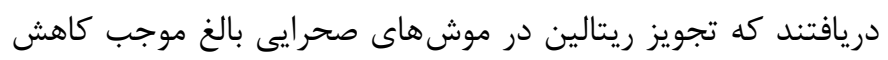
حجم و همجنين كاهش ميزان ميلين رشتههاى عصبى مى شود (9 (1). همانطور كه كفته شد متيلفنديت به عنوان يك داروى متداول براى درمان تمركز حافظه كودى استفاده مىشود. با اين وجود كزارش

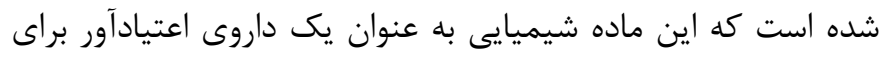

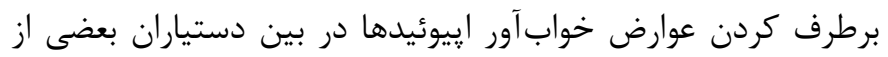

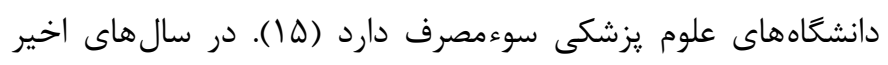

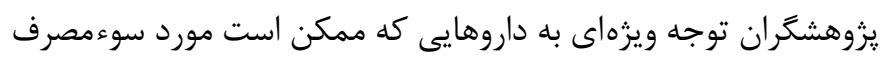

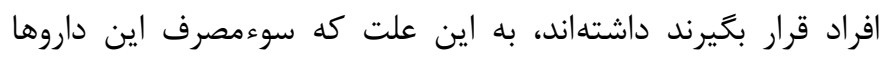
اثرات مخرب و زيانبارى را بر روى فرد به جا مى كذارد. مطالعات

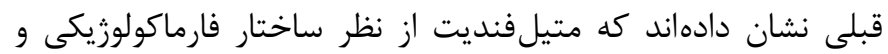
دارويى شبيه به برخى از مواد مخدر مانند متامفتامين و كوكائين است

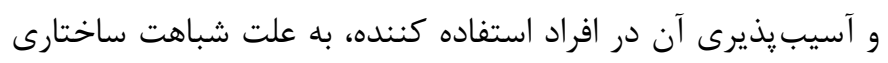

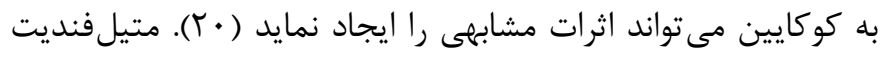

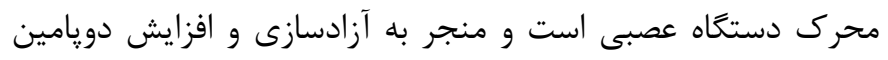

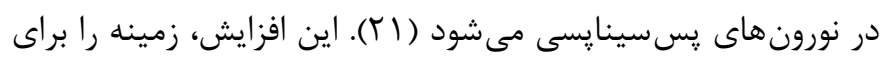

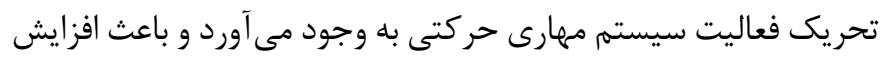

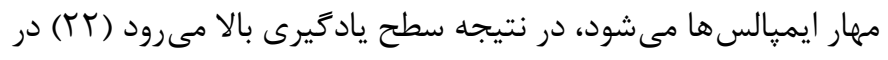

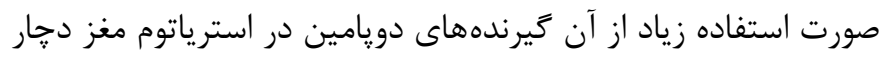
وابستكى مى شوند و نياز به تكرار استفاده پِيدا مى كنند (Yr). با توجه به

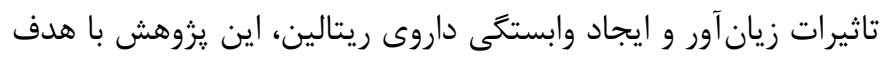

تخريب شوند، اين يديده با افزايش سن رابطه مستقيم دارد كه باعث

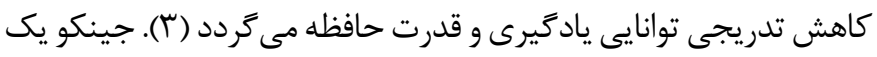

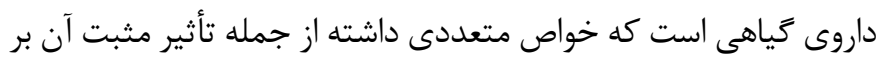

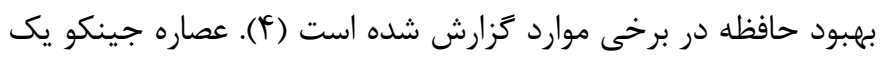

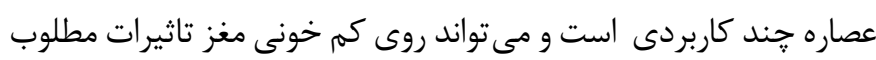

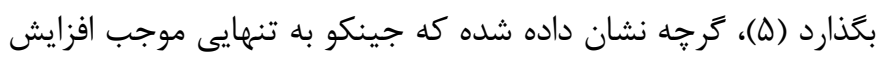

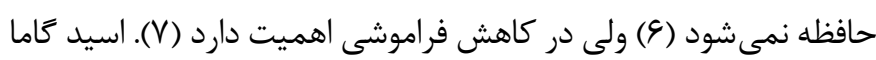

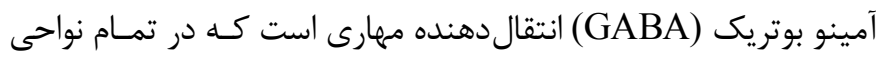
مغز انسان يافت مىشود و مشخص شده است كه در تقويت حافظه نقش

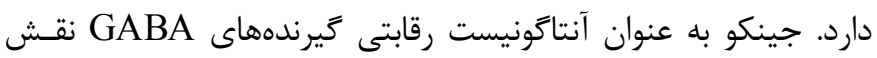

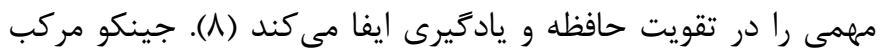

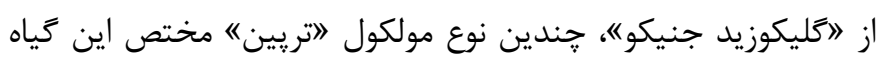

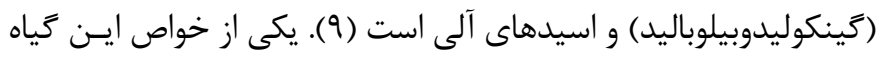

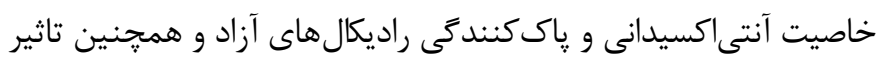

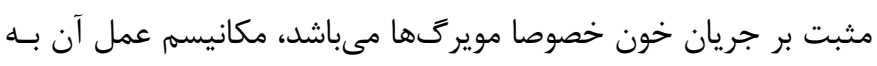

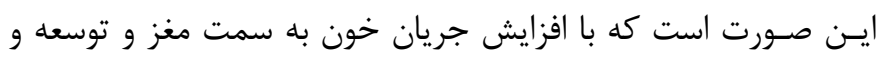

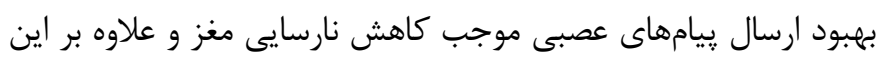
باعث بهبود كار مغز و تقويت حافظه مى شود (• (1).

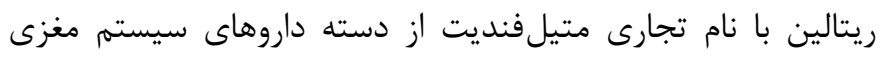
است كه با اثر بر قشر مغز و تالاموس و جلوكيرى از جذب مجدد

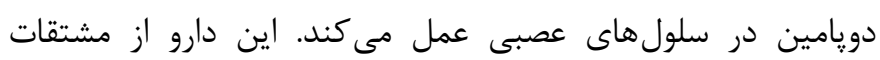

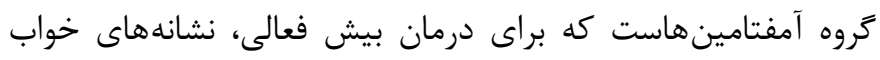

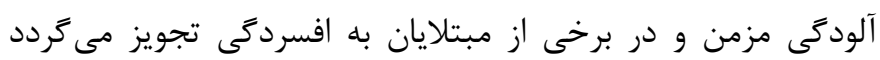

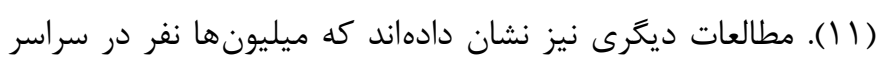

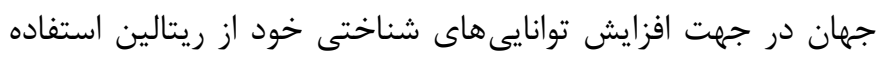

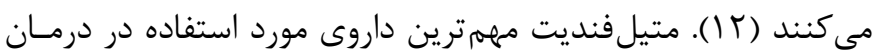

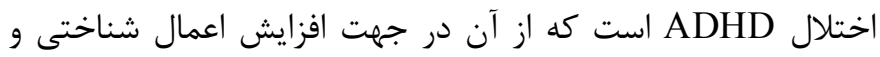

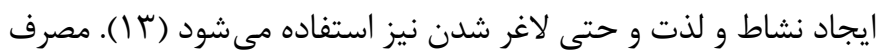
نامناسب متيلفنيدت ممكن است موجب ايجاد تحمل قابل ملاحظه و

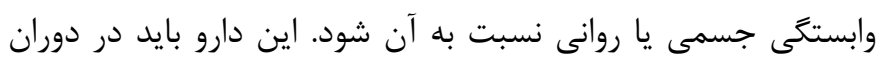

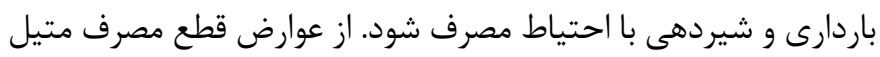

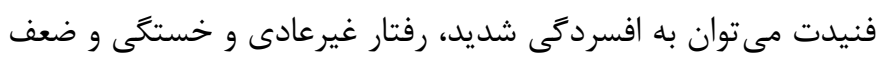

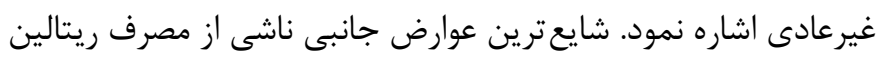

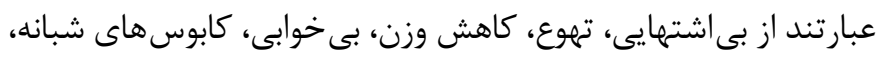

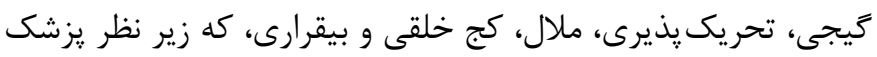

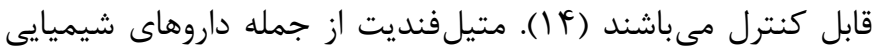
است كه هنوز مطالعه كافى بر روى آثار و عوارض احتمالى آن انجام 
مساوى، تاريك و روشن است كه به وسيله يك درب گيوتينى از يكديكر جدا شده است. در كف نيز داراى ميله هاى فولادى به قطر اه/ ميلى متر و

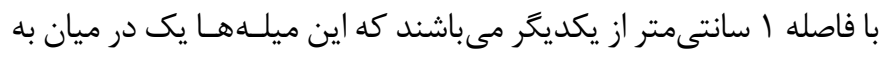

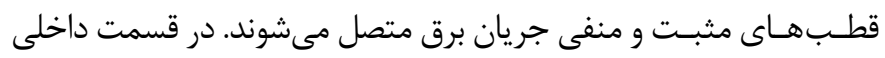

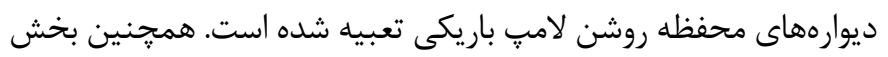

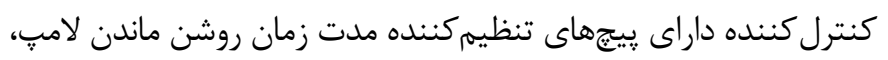
مدت زمان برقرارى شوك، ميـزان شوك از نظر فر كانس است. روش يادكيرى احترازى غير فعال: اين يادگيرى شامل سه مرحله عادت، آموزش، به ياديرى آحترآرى است. جلسه عادت: به منظور عادت دادن، حيوان را در بخش روشن دسـتكاه

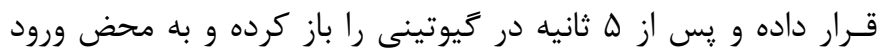

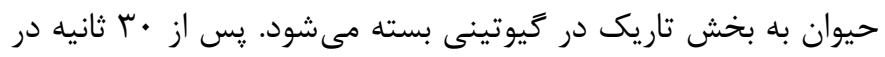

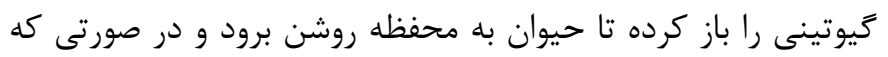

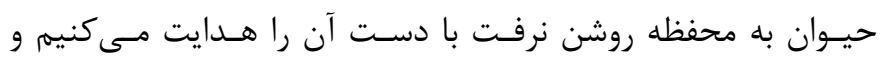

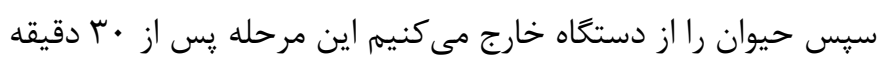
مجددا تكرار مى خردد. جلسه آموزش: بعد از كذشت ه دقيقه مجددًا حيوان به دستگاه

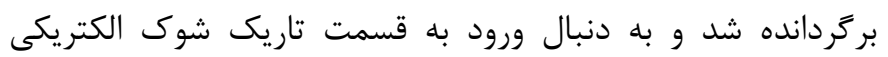

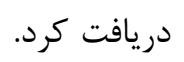

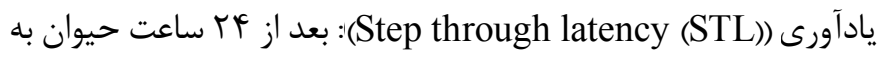

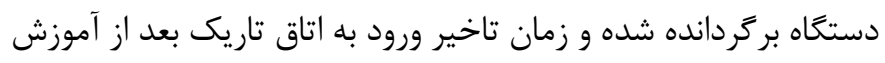

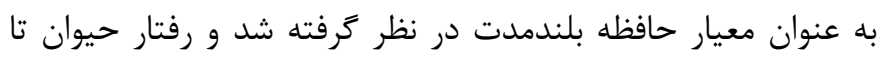

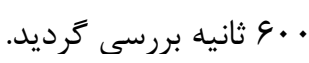

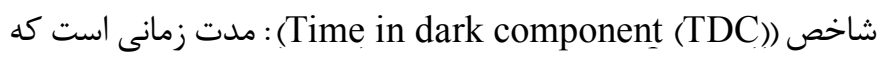
حيوان در جلسه آزمون ظرف مدت ل . 4 ثانيه در بخش تاريك دستكاه به سر مىبرد و شاخصى است كه با ميزان يادكيرى رابطه عكس دار دارد.

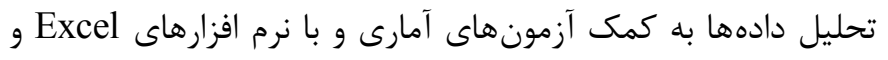

$$
\text { SPSS-23 }
$$

\section{يافته ها}

شاخصهاى توصيفى شامل ميانكين، انحراف معيار، انحراف معيار و

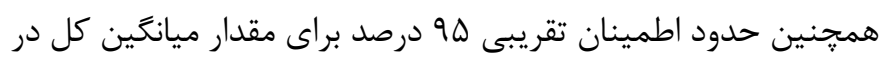
جدول شماره ا خلاصه شده است.

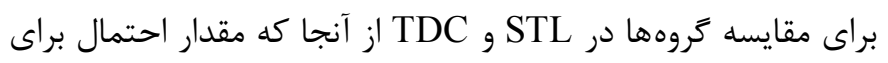

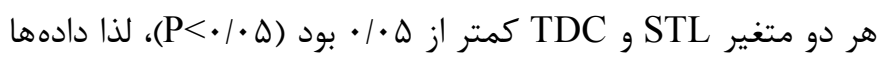
نرمال نبودند و از آزمون نايارامترى Kruskal-Wallis است كه نتايج در جدول شماره r خلاصه شده است.
بررسى اثر عصاره برى گياه جينكو بيلوبا بر حافظه موشهاى تحت

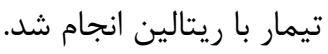

\section{روش كار}

يزوهش حاضر يك مطالعه تجربى بود كه در سال عوسا در خانه

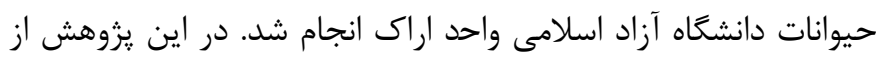

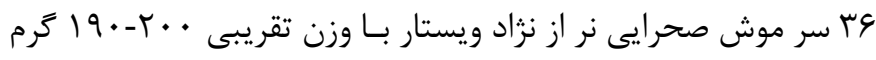

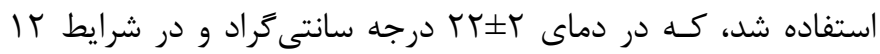
ساعت روشنايى و r| ساعت تاريكى نكَهدارى شدند. نمونهها به 4 كروه

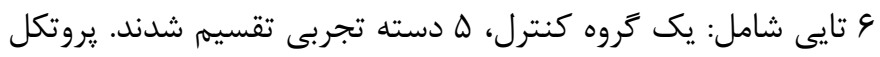

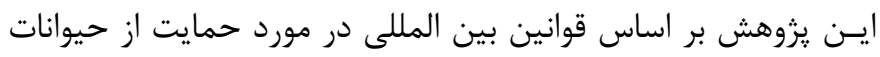

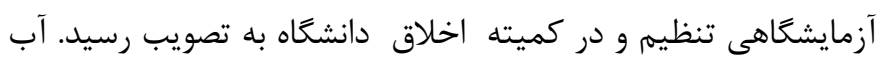

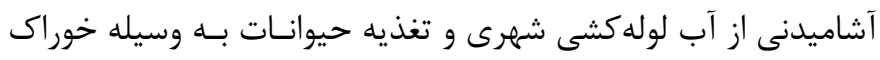
مخصوص موش شركت (غذاى فشرده) تهيه شده بود، به طور آزادانه در

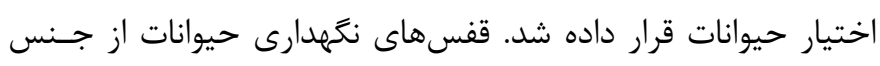

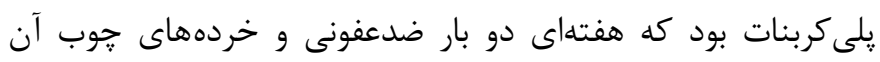
هر روز تعويض مى شد. به منظور سازش حيوانات با محيط آزمايشعاه

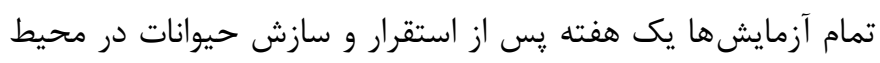

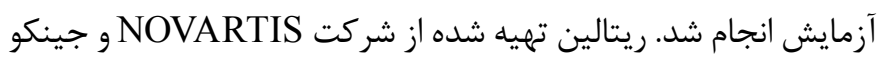

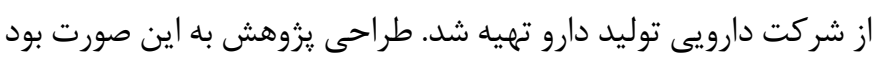

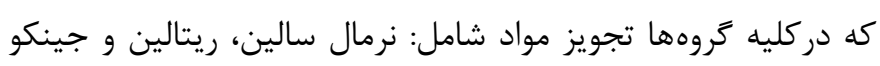

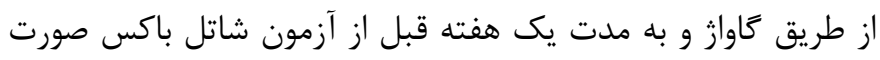

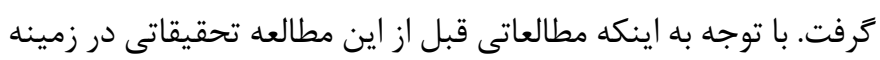

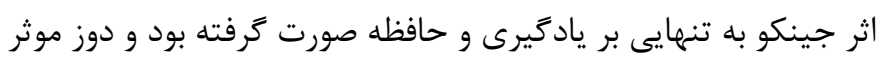

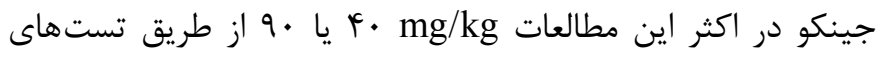

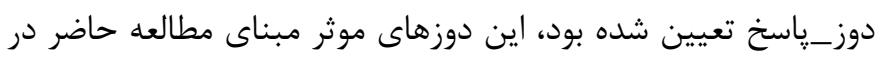

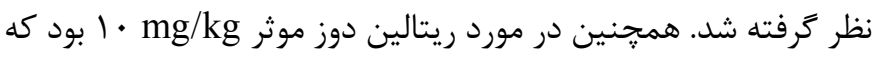
در مطالعه حاضر استفاده شد (TY).

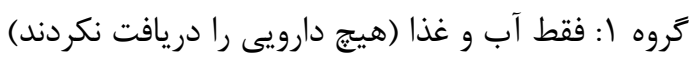
1·

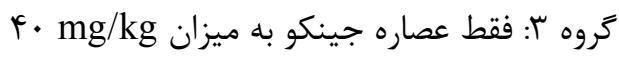
q. mg/kg كروه f

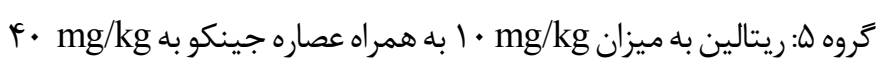

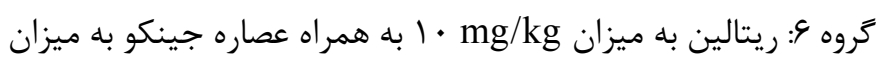
$9 \cdot \mathrm{mg} / \mathrm{kg}$ دستگًاه شاتل باكس: از دو بخش جعبه آموزش و بخش كنترل كننده

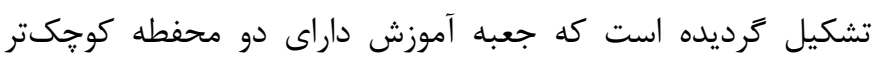




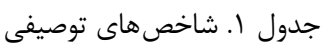

\begin{tabular}{|c|c|c|c|c|c|c|}
\hline 9 & $\Delta$ & f & $r$ & $r$ & 1 & كروهها \\
\hline eV/AT & $\mid \Delta V / I V$ & $\Delta T F / Q V$ & $G T / I V$ & $109 / 9 \mathrm{~V}$ & $1 \cdot \kappa / \Delta$. & STL ميانغين \\
\hline rqV/Aq & IDSINF & $V / / F q$ & $\| V / r \mid$ & |QT/৭Q & $|\Delta| / \& \Delta$ & انحراف معيار \\
\hline FV/ATEYKT/IF & $|\Delta V /| V \pm|r N| \cdot \Delta$ & $\Delta r F / G V \pm G F / \cdot \Lambda$ & $q T / I V \pm q \Delta / V$. & $|\Delta q / \S \vee \pm| r \Delta / V$ & $1 \cdot r / \Delta \cdot \pm \mid r r / q 9$ & فاصله اطمينان ه9 ٪ \\
\hline$r \mu / g V$ & kF/rr & $9 / \pi$ & 91 & $\Lambda \cdot / 0$. & 99 & ميانغين TDC \\
\hline$\Delta T / / Q$ & $V N|9|$ & $|\Delta / \Delta|$ & $4 \cdot / r V$ & QT/AT & $1 . \cdot / l^{f}$ & انحراف معيار \\
\hline$r r / G V \pm F r / Q \Lambda$ & $\mid \xi F / r r \pm g \xi / l \Lambda$ & ( & $q \mid \pm(q / r)$ & $\Lambda \cdot / \Delta \cdot \pm V \Delta / V \Lambda$ & 1)/Vब $\pm q \varepsilon$ & فاصله اطمينان ه9 ٪ \\
\hline
\end{tabular}

همجنين با بررسى بيشتر مقايسه بين تروهها در STL و TDC از دو

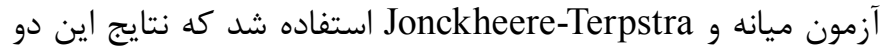

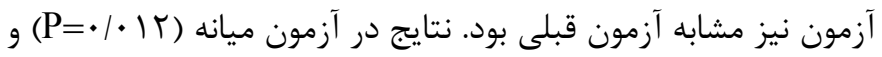

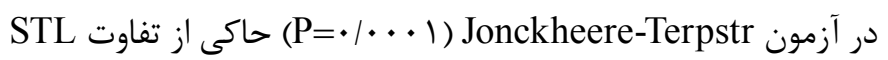
در كروهها بود، اما در TDC تفاوت معنادارى بين گرووهها در آزمون

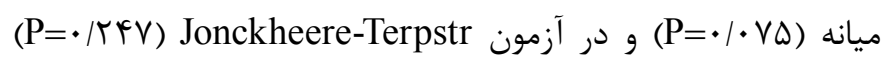

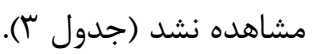

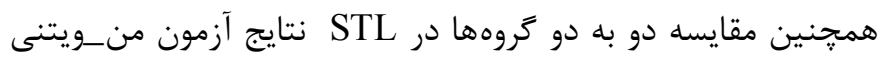

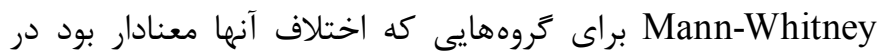
جدول أ خلاصه شده است.
با توجه به نتايج جدول r ملاحظه مى شود كه TDC در كروهها يكسان ولى STL در كروهها اختلاف معنادارى با هم دارند و از نظر ميانكين

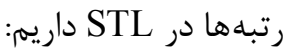

\begin{tabular}{|c|c|}
\hline $\mathbf{P}$ & كروهها \\
\hline${ }^{\prime} \cdot{ }_{r}$ & شاخص STL \\
\hline$\cdot$. TAN & شاخص TDC \\
\hline
\end{tabular}

جدول r. ترتيب ميانگين رتبهها در STL

\begin{tabular}{|c|c|c|c|c|c|c|}
\hline r & 1 & $\Delta$ & r & 9 & $f$ & ترتيب تروه تروهها \\
\hline $1 \cdot 10$. & $\cdot \wedge / 1$. & $\cdot N / 1 \Delta$ & $18 / 18$ & $G V / r G$ & $\Delta \cdot / r$. & ميانغين رتبه رتبهها \\
\hline
\end{tabular}

جدول Fا. مقايسه دو به دو مقدار STL كروهها به وسيله آزمون Mann-Whitney

\begin{tabular}{|c|c|c|c|}
\hline ميانغين تروه دوم & $\mathbf{P}$ & ميانغين كروه اول & تروهها \\
\hline Q/১. &.$\cdot \cdot r$ & $r / \omega$. & $1-f$ \\
\hline N/Ar & $.1 . Y 9$ & $F / I V$ & $1-9$ \\
\hline $9 / \Delta$. & H. & $r / \cdot \Delta$ & $r-\boldsymbol{r}$ \\
\hline $9 / \Delta$. &.$\cdot \cdot r$ & $\Gamma / \omega$. & $r-\boldsymbol{r}$ \\
\hline N/Ar &.$/ . T^{\prime}$ & $F / I V$ & $r-q$ \\
\hline$r / \Delta$. & $\cdot \cdot \cdot r$ & $9 / \Delta$. & $1-\Delta$ \\
\hline
\end{tabular}




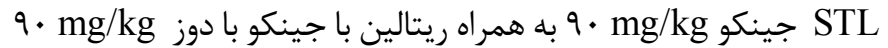
اختلاف معنادارى نداشت (ه • P<•). نمودار 1. مقايسه اثر دوزهاى مختلف جينكو و ريتالين با گروه كنترل بر ميزان STL واحدهاى اعداد گروهها برحسب mg/kg مىباشد. ميزان STL در كروه دريافت كننده جينكو

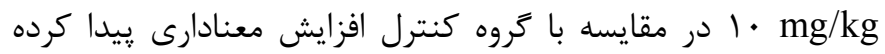
است. (ستون هاى ستارهدار نمايانكر افزايش معنادار سطح STL نسب إنب
طبق آزمون Mann-Whitney ميزان STL در گروه مصرف كننده جينكو

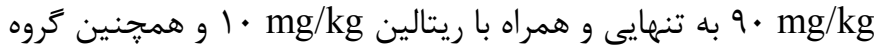

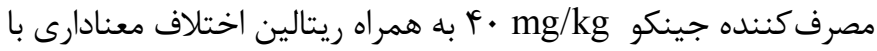

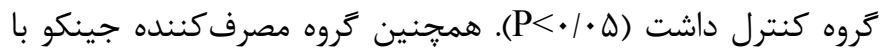
دوز mg/kg • اختلاف معنادارى با گروه مصرفكننده جينكو با دوز

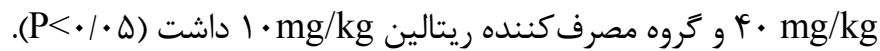
مصرف همزمان جينكو mg/kg •9 به همراه ريتالين اختلاف معنادارى ريناين

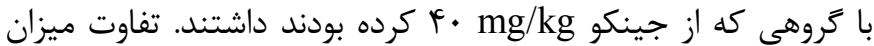

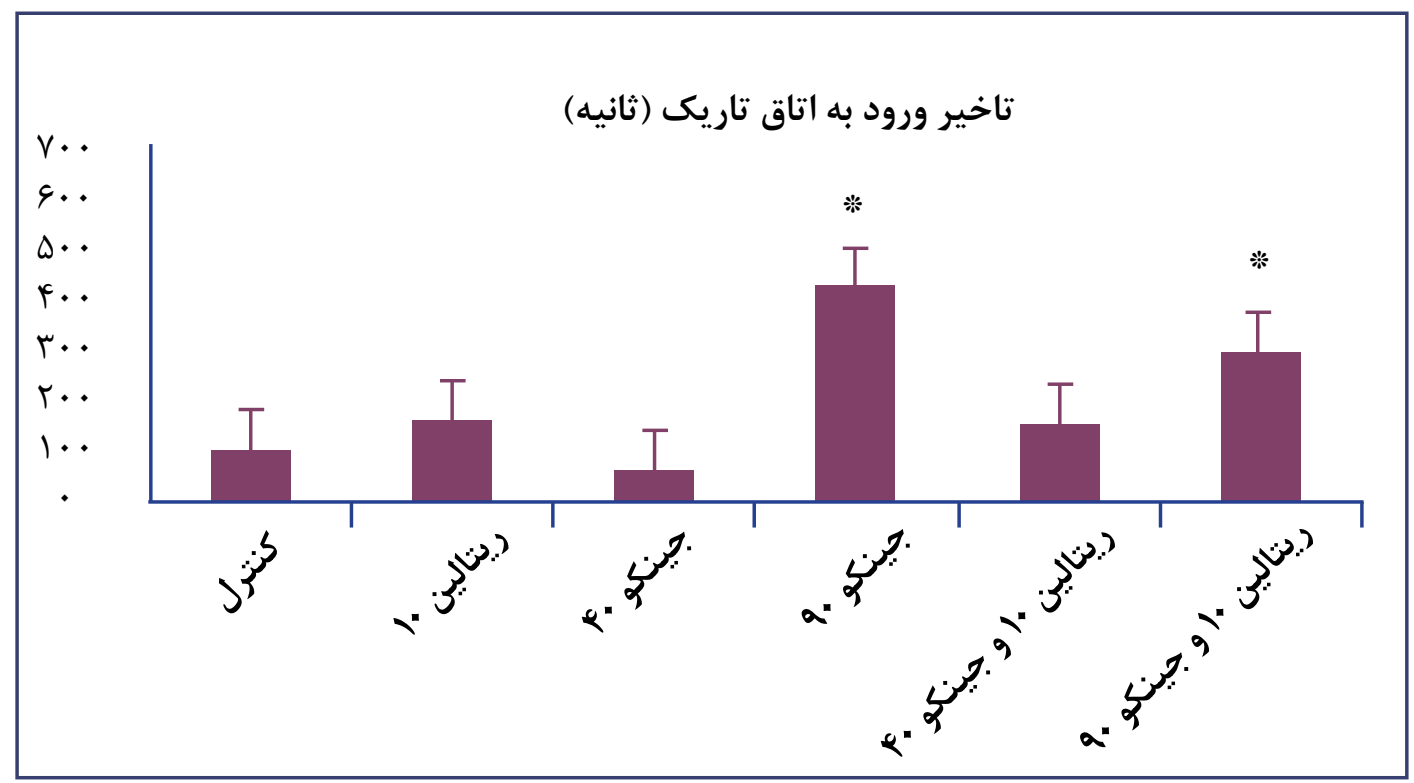

نمودار r. مقايسه اثر دوزهاى مختلف جينكو و ريتالين با كروه كنترل بر ميزان STL

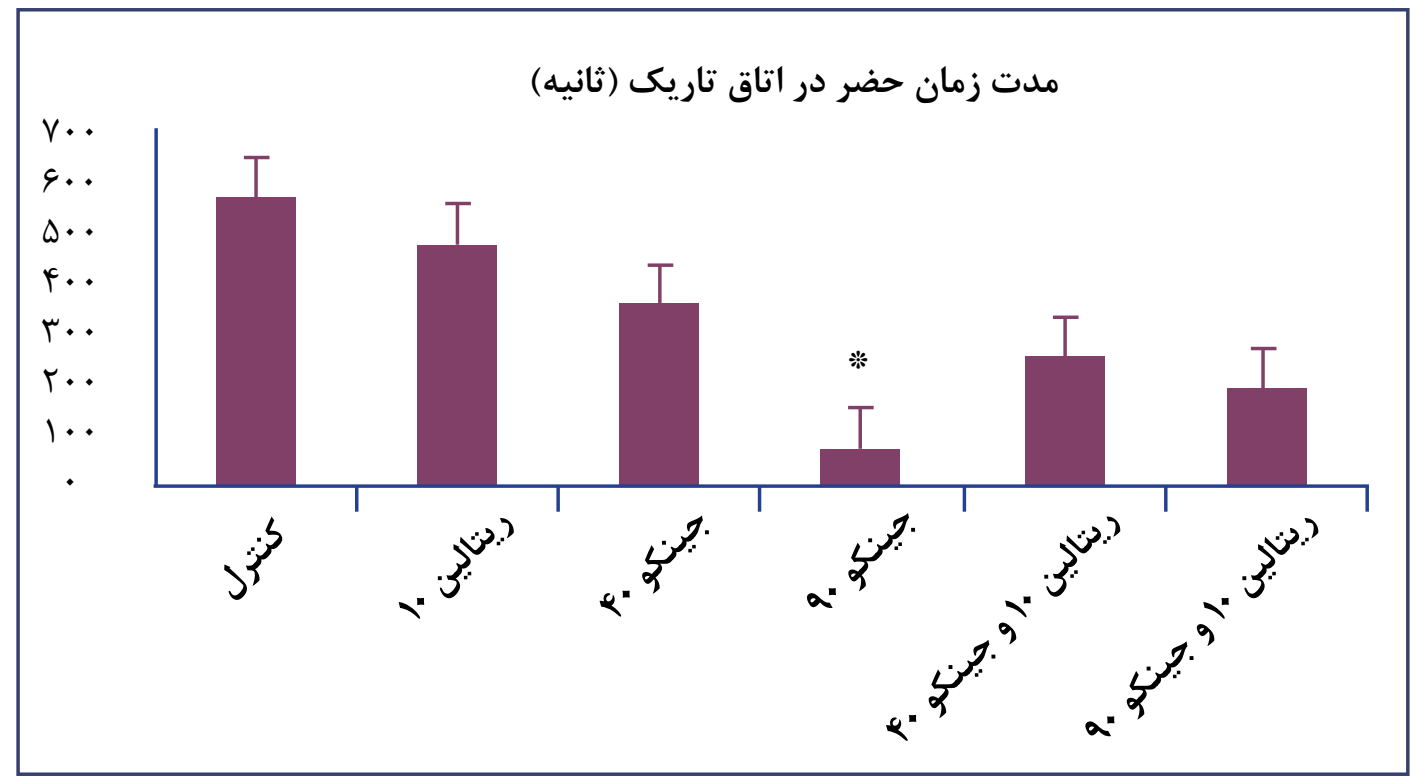

نمودار r. مقايسه اثر دوزهاى مختلف جينكو و ريتالين با كروه كنترل بر ميزان TDC 
سورى انجام گرفت، نتايج نشان داد كه دوز يايين آن بى اثر است و دوز بالا بر اساس وزن حيوان مى تواند ضايعات ساختمانى در سيستم عصبى ايجاد نمايد (צ). در يك مطالعه گزارش موردى براى اولين بار به احتمال سوءمصرف متيلفنديت در بيمارى كه

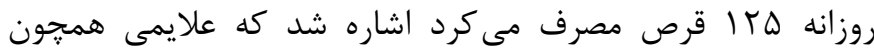
توهمزايى، يارانويا و سرخوشى را به همراه داشته است (TV).

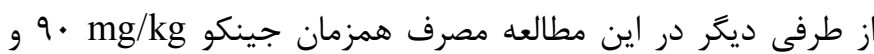

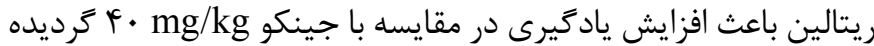
است. يس مصرف همزمان ريتالين و جينكو mg/kg •9 مى تواند در افرادى كه از جينكو به عنوان يك داروى كياهى استفاده مى كنند يادكيرى را افزايش دهد. جينكو نيز مىتواند از طريق اثر آنتى اكسيدانى و نيز با افزايش فاكتورهاى مربوط به رشد و تقويت كارايى سينايسى BDNF (فاكتور رشد مشتق از مغز) و همجنين NGF

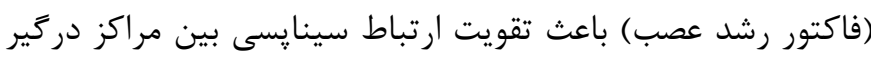
در ايجاد ياسخ شرطى احترازى غير فعال شود. اين مراكز شامل

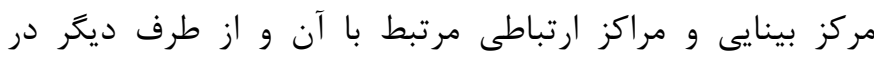
ارتباط با شوك به عنوان محرك غير شرطى اميخدال مى باشد كه در ايجاد يادگيرىهاى مرتبط با استرس دخالت دارد. جينكو احتمالا مى تواند از طريق تقويت محور HPA (هييوتالاموس، هييوفيز و غدد فوق كليه) هم عمل كند. تقويت اين محور يا همان محور استرس موجب ترشح بيشتر كورتيزول، افزايش كلوكز مغز و افزايش كلسيم در دسترس جهت ارتباطات سينايسى مىباشد. جينكو يكى از كياهانى است كه تاثير مثبت آن بر بهبود حافظه كزارش شده است.

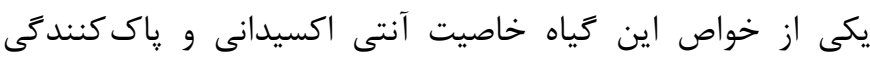
راديكال هاى آزاد و همجنين تأثير مثبت بر جريان خون خصوصا در مويركها مىباشد. مكانيسم عمل آن بدين صورت است كه با افزايش جريان خون به سمت مغز و توسعه و بهبود ارسال ييام هاى عصبى موجب كاهش نارسايى مغز و علاوه بر اين باعث بهبود كار مغز و تقويت حافظه مى شود (9).

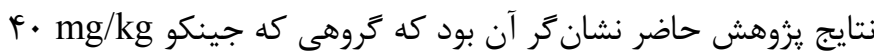
را مصرف كرده بودند نسبت به تروه كنترل افزايش يادگيرى

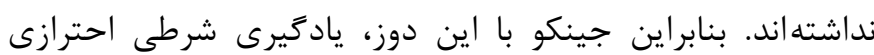

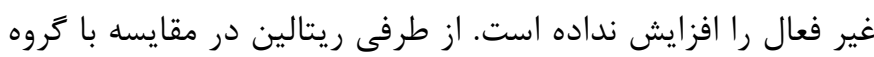
كنترل هم باعث افت يادكيرى نشده، همجنين مصرف ريتالين به

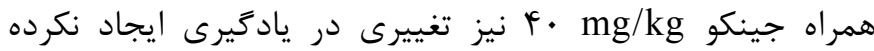
است. ضمن اينكه جينكو با اين دوز در افراد سالم باعث افزايش يادكيرى نمى شود. نوشينفر و همكاران در مطالعه خود به اين
نتايج به دست آمسده در مورد تأثير مصرف جينكو با دوزهاى مختلف به همراه ريتالين و به صورت جداكانه و مقايسه آن با حيوانات كروه

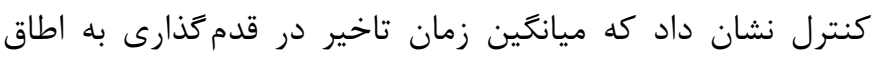
تاريك (به عنوان يكى از شاخص هاى حافظه) و مدت اقامت در اتاق داق دان تاريك در تست احترازى غير فعال نشانى آنار تأثير افزايشى مصرف جينكو mg/kg •9 بر ياد واقع نتايج مربوط به STL نشان كر آن است كه مقدار اين شاخص

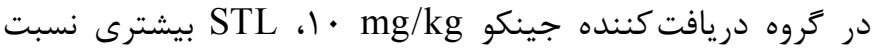
mg/kg به گروه كنترل دارد و اين اختلاف معنادار بود. جينكوه •و در مقايسه با ريتالين اثر بيشترى را روى يادگيرى داشت اما زمانى كه با ريتالين همراه شده بود اين اثر افزايش ييدا كرد. نتايج

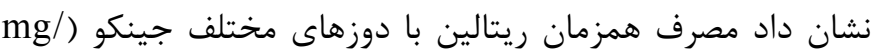

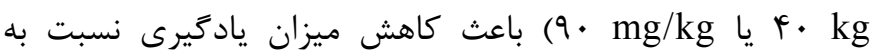
جينكو mg/kg • 9 به تنهايى شده است. گروه مصرف كننده جينكو •9 به تنهايى و همراه با ريتالين هر دو باعث افزايش يادكيرى شرطى احترازى غير فعال در مقايسه با گروه كنترل شده بود اين در حالى است كه كروهى كه ريتالين مصرف كرده بودند اختلاف معنادارى با گروه كنترل نداشتند. بنابراين ريتالين باعث تغييرى در يادَيرى نشده ولى مصرف همزمان آن با جينكو افزايش يادكيرى در مقايسه با گروه كنترل شده است. لذا استفاده ريتالين به طور همزمان با جينكو

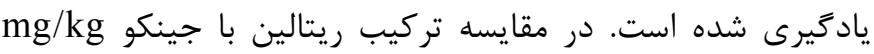

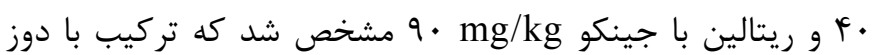
بالاتر جينكو باعث يادكيرى بيشترى در موشها شده است، بنابراين در مصرفكنندكان ريتالين، مصرف همراه با جينكو با دوز بالاتر مى تواند يادگيرى شرطى احترازى غيرفعال را افزايش دهد. ريتالين به عنوان يك ماده افزايش دهنده قدرت تمركز، احتمالا با لإيا افزايش ميانجى هاى عصبى كلوتامات و آسيارتات در مراكزى از مغز

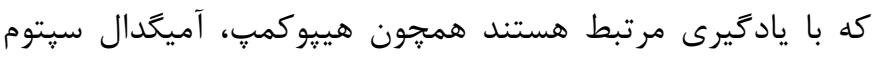

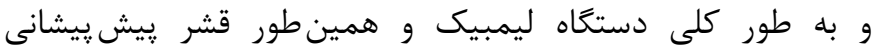

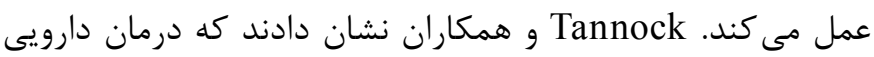
(ريتالين) سبب بهبود حافظه فعال كودكان دهار ADHD مىشود، همجنين سطح فعاليت حركتى آنها را كاهش مىدهد كه با نتايج اين تحقيق همخوانى ندارد. علت آن مى تواند به تفاوت دوز مصرفى و نيز مدل مورد بررسى بركردد (Wه). در يزوهشى كه در آن تزريق داخل صفاقى ريتالين به شكل وابسته به دوز بر روى موشهاى برد 


\section{نتيجه كَيرى}

نتايج نشان داد مصرف جينكو mg/kg • 9 باعث افزايش سطح يادگيرى شرطى احترازى غير فعال مىشود. در مجموع نتايج اين تحقيق بيان اثر مثبت دوز • ج جينكو به تنهايى و همراه با ريتالين بر يادگيرى احترازى موش هاى تحت تيمار با ريتالين است.

\section{تشكر و قدرقاذى}

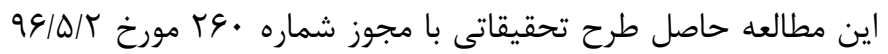

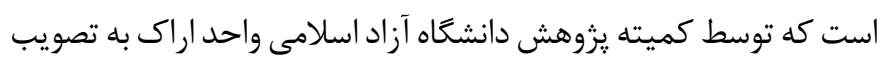
رسيده است. بدينوسيله از زحمات كليه همكاران و شركت كنند انجام اين مطالعه تشكر و قدردانى به عمل مى آيد.

\section{References}

1. Baddeley AD. Working memory: Theories, models, and controversies. Annual Review of Psychology. 2012;63:1-29.

2. Saadati A, Kiamanesh A, Kadivar P, Ali Hamidi M. Working memory, reading performance and academic achievement in male monolingual and bilingual students. Quarterly Journal of Educational Innovations. 2010;9(3):89-124. (Persian)

3. Aboukhatwa M, Dosanjh L, Luo Y. Antidepressants are a rational complementary therapy for the treatment of Alzheimer's disease. Molecular Neurodegeneration. 2010;5(1):10.

4. Stough C, Clarke J, Lloyd J, Nathan PJ. Neuropsychological changes after 30-day Ginkgo biloba administration in healthy participants. International Journal of Neuropsychopharmacology. 2001;4(2):131-134.

5. Tulsulkar J, Shah ZA. Ginkgo biloba prevents transient global ischemia-induced delayed hippocampal neuronal death through antioxidant and anti-inflammatory mechanism. Neurochemistry International. 2013;62(2):189-197.

6. Solomon PR, Adams F, Silver A, Zimmer J, DeVeaux R. Ginkgo for memory enhancement: A randomized controlled trial. Jama. 2002;288(7):835-840.

7. Stackman RW, Eckenstein F, Frei B, Kulhanek D, Nowlin J, Quinn JF. Prevention of age-related spatial memory deficits in a transgenic mouse model of Alzheimer's disease by
نتيجه رسيدند كه تجويز جينكو با مقدار f mg/kg قادر به جلو كيرى از اختلال حافظه القا شده نمى باشد كه تا حدى با نتايج يزوهش حاضر همسو مىباشد (9). در فرايند حافطه و يادگيرى انتقال دهندهاى استيل كولين و دويامين داراى نقش كليدى هستند به طورى كه يزوهش ديخر محققين اين مطالعه نشان داد كه داروى ترى هذزى فنيديل به عنوان آنتاگونيست استيل كولين و موسيقى آرام به ترتيب با مهار و افزايش فعاليت نورونهاى دوريامينرزيك، ترجيح مكان شرطى القا شده با مورفين را كاهش

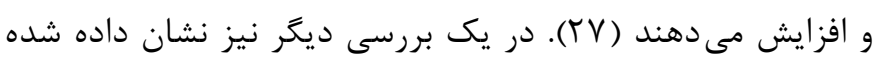
است كه بوسيرون بـه عنوان آنتاگونيست سروتونين باعث تقويت اعمال شناختى مى شود ( (1)).

chronic Ginkgo biloba treatment. Experimental Neurology. 2003;184(1):510-520.

8. Bing Y, Zhaobao W. Effects of Ginkgo biloba extract on free radical metabolism of liver in mice during endurance metabolism. African Journal of Traditional, Complementary and Alternative Medicines. 2010;7(4):291-295.

9. Nooshinfar E, Sabet-Kasaie M. A study of the effect of Ginkgo biloba extract on MK801 induced forgetfulness in rats. Physiology and Pharmacology. 2010;10(4):275-282. (Persian) 10. Singh J, Kakkar P. Antihyperglycemic and antioxidant effect of Berberis aristata root extract and its role in regulating carbohydrate metabolism in diabetic rats. Journal of Ethnopharmacology. 2009;123(1):22-26.

11. Patel MB, Mishra S. Hypoglycemic activity of alkaloidal fraction of Tinospora cordifolia. Phytomedicine. 2011;18(12):1045-1052.

12. Motaghinejad M, Motevalian M, Shabab B. Effects of chronic treatment with methylphenidate on oxidative stress and inflammation in hippocampus of adult rats. Neuroscience Letters. 2016;619:106-113.

13. Manjanatha MG, Shelton SD, Dobrovolsky VN, Shaddock JG, McGarrity LG, Doerge DR, et al. Pharmacokinetics, doserange, and mutagenicity studies of methylphenidate hydrochlo- 
ride in B6C3F1 mice. Environmental and Molecular Mutagenesis. 2008;49(8):585-593.

14. Gonçalves J, Baptista S, Martins T, Milhazes N, Borges F, Ribeiro CF, et al. Methamphetamine-induced neuroinflammation and neuronal dysfunction in the mice hippocampus: Preventive effect of indomethacin. European Journal of Neuroscience. 2010;31(2):315-326.

15. Daniali S, Nahavandi A, Madjd Z, Shahbazi A, Niknazar S, Shahbazzadeh D. Chronic Ritalin administration during adulthood increases serotonin pool in rat medial frontal cortex. Iranian Biomedical Journal. 2013;17(3):134-139.

16. Van Der Marel K, Bouet V, Meerhoff GF, Freret T, Boulouard M, Dauphin F, et al. Effects of long-term methylphenidate treatment in adolescent and adult rats on hippocampal shape, functional connectivity and adult neurogenesis. Neuroscience. 2015;309:243-258.

17. Khademi L, Shariat SV. Prevalence of nonmedical use of Methylphenidate (Ritalin) in residents of Tehran University of Medical Sciences and their attitude toward Methylphenidate use. Iranian Journal of Psychiatry \& Clinical Psychology. 2013;19(1):20-27. (Persian)

18. Arria AM, Wish ED. Nonmedical use of prescription stimulants among students. Pediatric Annals. 2006;35(8):565-571. 19. Tavakoli F, Hoseini SE, Mokhtari M, Vahdati A. Effect of memory attenuation and light music on morphine dependency in male mature mice using conditioned place preference. Journal of Kashan University of Medical Sciences (FEYZ). 2014;18(1):1-8.

20. Monaco CM, Gebhardt KM, Chlebowski SM, Shaw KE, Cheng JP, Henchir JJ, Zupa MF, Kline AE. A combined therapeutic regimen of buspirone and environmental enrichment is more efficacious than either alone in enhancing spatial learn- ing in brain-injured pediatric rats. Journal of Neurotrauma. 2014;31(23):1934-1941.

21. Kermanian F, Mehdizadeh M, Soleimani M, Bideskan AR, Asadi-Shekaari M, Kheradmand $\mathrm{H}$, et al. The role of adenosine receptor agonist and antagonist on Hippocampal MDMA detrimental effects; A structural and behavioral study. Metabolic Brain Disease. 2012;27(4):459-469.

22. Soleimani Asl S, Mousavizedeh K, Pourheydar B, Soleimani M, Rahbar E, Mehdizadeh M. Protective effects of N-acetylcysteine on 3, 4-methylenedioxymethamphetamine-induced neurotoxicity in male Sprague-Dawley rats. Metabolic Brain Disease. 2013;28(4):677-686.

23. Konstenius M, Jayaram-Lindström N, Beck O, Franck J. Sustained release methylphenidate for the treatment of ADHD in amphetamine abusers: A pilot study. Drug and Alcohol Dependence. 2010;108(1-2):130-133.

24. Das A, Shanker G, Nath C, Pal R, Singh S, Singh H. A comparative study in rodents of standardized extracts of Bacopa monniera and Ginkgo biloba: Anticholinesterase and cognitive enhancing activities. Pharmacology, Biochemistry, and Behavior. 2002;73(4):893-900.

25. Tannock R, Ickowicz A, Schachar R. Differential effects of methylphenidate on working memory in ADHD children with and without comorbid anxiety. Journal of the American Academy of Child \& Adolescent Psychiatry. 1995;34(7):886-896.

26. Comim CM, Gomes KM, Reus GZ, Petronilho F, Ferreira GK, Streck EL, Dal-Pizzol F, Quevedo J. Methylphenidate treatment causes oxidative stress and alters energetic metabolism in an animal model of attention-deficit hyperactivity disorder. Acta Neuropsychiatrica. 2014;26(2):96-103.

27. McCormick, Jr, T, McNeel TW. Acute psychosis and Ritalin abuse. The Journal of Texas Medicine. 1963;59:99-100. 